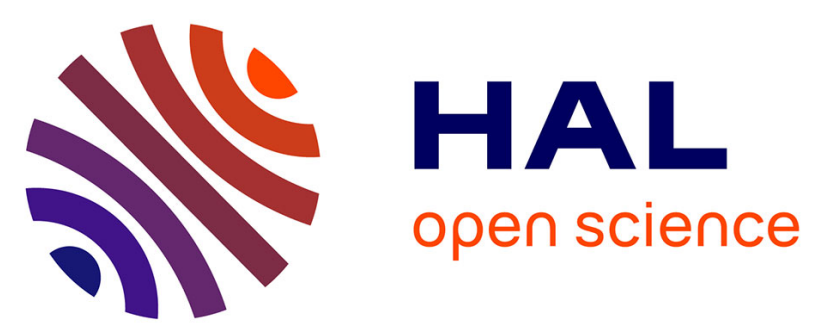

\title{
A revised radiocarbon chronology of the aceramic shell midden of Ra's al-Hamra 6 (Muscat, Sultanate of Oman): implication for occupational sequence, marine reservoir, and human mobility
}

Antoine Zazzo, Olivia Munoz, Emilie Badel, Irène Béguier, Francesco Genchi, Lapo Gianni Marcucci

\section{To cite this version:}

Antoine Zazzo, Olivia Munoz, Emilie Badel, Irène Béguier, Francesco Genchi, et al.. A revised radiocarbon chronology of the aceramic shell midden of Ra's al-Hamra 6 (Muscat, Sultanate of Oman): implication for occupational sequence, marine reservoir, and human mobility. Radiocarbon, 2016, 58

(2), pp.383 - 395. 10.1017/RDC.2016.3 . halshs-01479001

\author{
HAL Id: halshs-01479001 \\ https://shs.hal.science/halshs-01479001
}

Submitted on 8 Dec 2020

HAL is a multi-disciplinary open access archive for the deposit and dissemination of scientific research documents, whether they are published or not. The documents may come from teaching and research institutions in France or abroad, or from public or private research centers.
L'archive ouverte pluridisciplinaire HAL, est destinée au dépôt et à la diffusion de documents scientifiques de niveau recherche, publiés ou non, émanant des établissements d'enseignement et de recherche français ou étrangers, des laboratoires publics ou privés. 


\title{
A REVISED RADIOCARBON CHRONOLOGY OF THE ACERAMIC SHELL MIDDEN OF RA'S AL-HAMRA 6 (MUSCAT, SULTANATE OF OMAN): IMPLICATION FOR OCCUPATIONAL SEQUENCE, MARINE RESERVOIR AGE, AND HUMAN MOBILITY
}

\author{
Antoine $\mathrm{Zazzo}^{1 *} \cdot \mathrm{Olivia} \mathrm{Munoz}^{2} \cdot$ Emilie Badel$^{2} \cdot$ Irène Béguier $^{3} \cdot$ Francesco Genchi $^{4} \cdot \mathrm{Lapo}$ Gianni \\ Marcucci $^{2,5}$ \\ ${ }^{1}$ Unité Mixte de Recherche 7209 “Archéozoologie, Archéobotanique: Sociétés, Pratiques et Environnements”, Centre \\ National de la Recherche Scientifique, Muséum national d'histoire naturelle, Sorbonne Universités, CP 56, 55 rue \\ Buffon, F-75005 Paris, France. \\ ${ }^{2}$ Université Paris 1 Panthéon-Sorbonne, UMR 7041, Archéologie et Sciences de l'Antiquité, Equipe “du Village à l'Etat \\ au Proche et Moyen Orient," Maison de l'Archéologie et de l'Ethnologie, F-92023 Nanterre, France. \\ 3 Service départemental d'archéologie du Calvados, 9, rue Saint-Laurent, BP 20520, 14035 Caen, Cedex 1, France. \\ ${ }^{4}$ Università di Bari, Dipartimento dei Beni Culturali e Scienze del Linguaggio, Palazzo Ateneo, Piazza Umberto I 1, I- \\ 70125 Bari, Italy. \\ ${ }^{5}$ Università di Bologna, Dipartimento di Archeologia, Piazza San Giovanni in Monte 2, 40124 Bologna, Italy. \\ *Corresponding author. Email: zazzo@mnhn.fr.
}

\begin{abstract}
Ra's al-Hamra 6 (RH-6) is one of the earliest stratified archaeological sites along the eastern littoral of the Arabian Peninsula. This shell midden was radiocarbon dated to the $6^{\text {th }}-5^{\text {th }}$ millennium cal $\mathrm{BC}$, but the majority of the dates were obtained before the advent of accelerator mass spectrometry (AMS) ${ }^{14} \mathrm{C}$ dating and suffer from large uncertainties. In addition, most of these dates were obtained on marine and mangrove shells and required correction for local variations from the global average marine $14 \mathrm{C}$ reservoir age (MRA). This proved difficult because no consensus value exists for this period in the area. Recent excavations at RH-6 offered the opportunity to redate this important site in order to precisely determine its occupation history and later use as a graveyard, and establish the marine reservoir effect for this time period. Thirty-eight samples of charcoal, shells, and human bone apatite were selected for ${ }^{14} \mathrm{C}$ dating. Bayesian modeling of the ${ }^{14} \mathrm{C}$ dates suggests that the formation of the shell midden spanned $\sim 1$ millennium, between the mid- $6^{\text {th }}$ and the mid- $5^{\text {th }}$ millennium cal BC. Positive and consistent $\Delta \mathrm{R}$ values were calculated throughout the entire sequence, ranging from $99 \pm 27$ to $207 \pm 43{ }^{14} \mathrm{C}$ yr. At the beginning of the $4^{\text {th }}$ millennium cal BC, RH-6 was used as a graveyard, as suggested by the ${ }^{14} \mathrm{C}$ dating of a shell in strict association with an individual buried at the surface of the site. ${ }^{14} \mathrm{C}$ dating of human bone apatite allowed us to calculate that $89 \%$ of this individual's diet derived from marine resources. This finding confirms previous observations showing the overwhelming presence of marine and mangrovedwelling species in the faunal and charcoal assemblage, and implies a low mobility, or mobility restricted to the coast for this population during the $4^{\text {th }}$ millennium cal BC.
\end{abstract}

KEYWORDS: Eastern Arabian littoral, burial, sea-level change, mangrove, Bayesian modeling. 
[Authors version] How to cite this article:

Antoine Zazzo, Olivia Munoz, Emilie Badel, Irène Béguier, Francesco Genchi and Lapo Gianni Marcucci (2016) A Revised Radiocarbon Chronology of the Aceramic Shell Midden of Ra's Al-Hamra 6 (Muscat, Sultanate of Oman): Implication For Occupational Sequence, Marine Reservoir Age, and Human Mobility. Radiocarbon, $58: 383$ - 395. Available on CJO 2016 doi:10.1017/RDC.2016.3

\section{INTRODUCTION}

Ra's al-Hamra 6 (RH-6) belongs to a set of prehistoric settlements distributed on the headland of Ra's alHamra and the adjacent Qurum mangrove swamp in the Muscat Capital area (Sultanate of Oman) (Figure 1). Among the 12 archaeological sites surveyed in the $1970 \mathrm{~s}$, RH- 6 is, together with the neighboring site of RH-5, the only site surviving the massive urbanization of the capital area (Tosi 1975; Marcucci et al. 2014). This shell midden provided significant activity and domestic evidence and a burial ground that shed light on the way of life of ancient fisher-herders-gatherers from eastern Arabia. Despite extensive research focusing on the material culture (Biagi 1985; Biagi and Nisbet 1999) and the exploitation of the local environment (Biagi and Travers 1985; Biagi and Nisbet 1992, 1999) by the communities that settled in the Ra's al-Hamra area at that time, the chronology of occupation of the site remains poorly constrained. Based on the limited number of radiocarbon dates available for RH- 6 so far, the site could have been occupied for about $700 \mathrm{yr}$, between the middle of the $6^{\text {th }}$ and the beginning of the $5^{\text {th }}$ millennium cal BC, approximately 1 millennium before the nearby site of RH-5 (Biagi 1994). This makes RH-6 one of the oldest stratified sites in the Arabian Peninsula.

${ }^{14} \mathrm{C}$ dates, however, were mainly obtained before the advent of $\mathrm{AMS}{ }^{14} \mathrm{C}$ dating, and suffer from large uncertainties ( $\pm 70 \mathrm{yr}$ on average). Carbon isotope values were not measured, and the dates were not corrected for isotopic fractionation. Moreover, most dates were obtained on marine (Anadara sp.) and mangrove (Terebralia palustris) shells. Marine artifacts (sea shells, fish bones) provide an abundant source of carbon, which is technically easy to date, but ${ }^{14} \mathrm{C}$ dates cannot be directly used to infer calendar ages because of the so-called "marine reservoir effect."

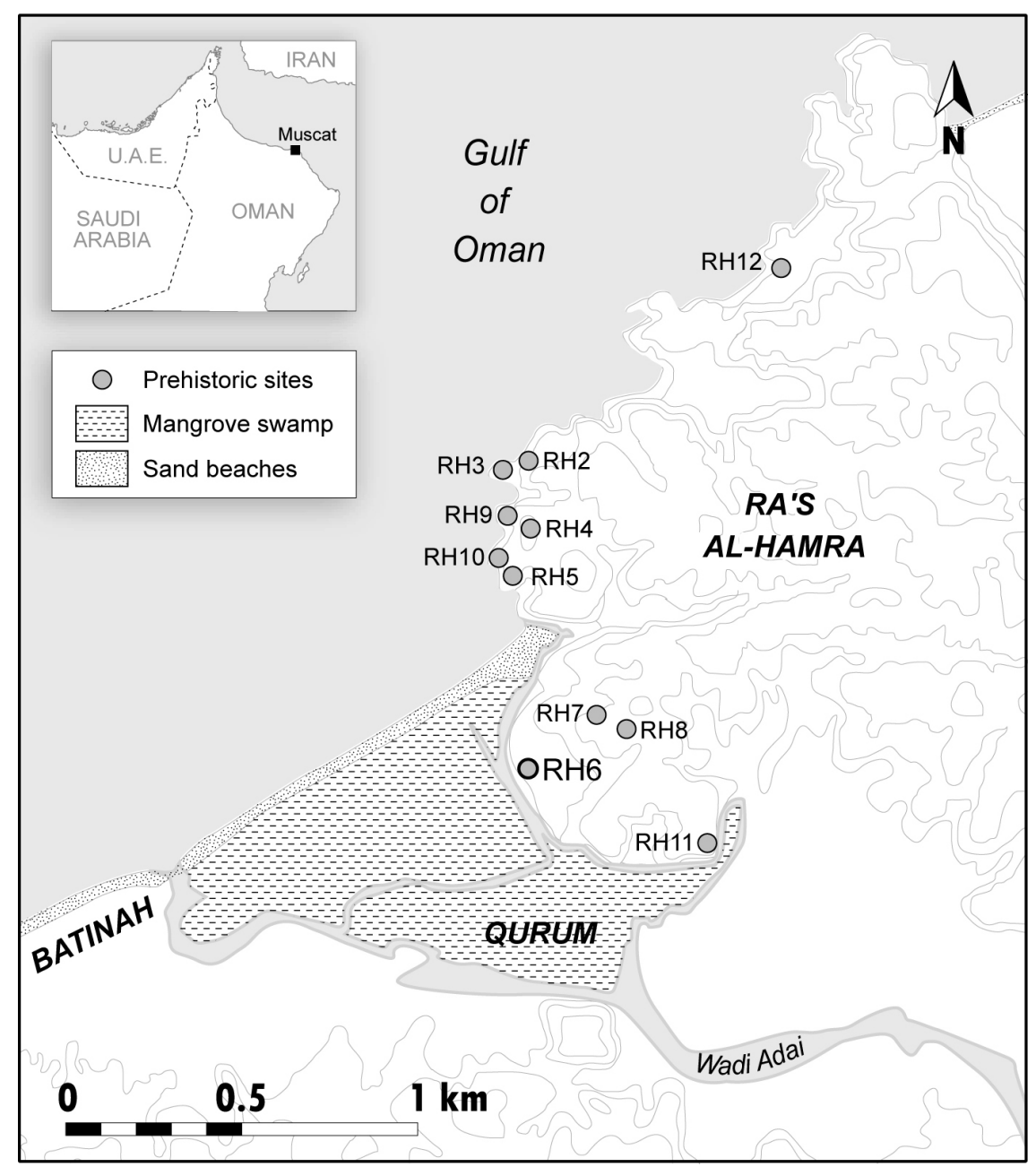

Figure 1 - Location of Ra's al-Hamra $6($ RH-6) and other prehistorical sites in the area of Ra's al-Hamra and Qurum (Muscat, Oman). 
[Authors version] How to cite this article:

Antoine Zazzo, Olivia Munoz, Emilie Badel, Irène Béguier, Francesco Genchi and Lapo Gianni Marcucci (2016) A Revised Radiocarbon Chronology of the Aceramic Shell Midden of Ra's Al-Hamra 6 (Muscat, Sultanate of Oman): Implication For Occupational Sequence, Marine Reservoir Age, and Human Mobility. Radiocarbon, 58 : 383 - 395. Available on CJO 2016 doi:10.1017/RDC.2016.3

Dates need to be corrected for local variations from the global average marine ${ }^{14} \mathrm{C}$ reservoir age (MRA). Because this value is likely to change over time, it is not possible to apply a modern value to previous time intervals. The standard procedure for determining local reservoir ages in archaeological sites is to compare the age measured between coeval terrestrial and marine pairs that have no inbuilt age. This proved difficult in Oman and there is currently no consensus value for the MRA at that time in the area. Previous estimates of the MRA based on associated shells and charcoal vary by about $400{ }^{14} \mathrm{C}$ yr and this was a serious limitation to the establishment of a precise chronology in the area based on marine material (Uerpmann 1991; Biagi 1994; Zazzo et al. 2012).

The dating of the graveyard also is problematic. In the absence of datable associated material, only one individual was dated and this returned an age of $\sim 2000$ cal BC, suggesting that RH-6 was still occupied during the Bronze Age (Hedges et al. 1997; Biagi 1999). The ${ }^{14} \mathrm{C}$ date was allegedly obtained on bone collagen, but previous work at $\mathrm{RH}-5$ showed that bone collagen is not preserved in Omani sites from the Neolithic due to harsh climatic conditions, suggesting that recent contamination, instead of pure collagen, could have been dated. Furthermore, the stratigraphic evidence, the typology of the graves, the position of the individuals, and the total absence of material datable to the Bronze Age (e.g. metal) in association with the grave or on the site suggest that the graves are likely contemporaneous with the latest phases of the settlement occupation, that is, the $5^{\text {th }}$ millennium cal BC (Munoz 2014).

Recent excavations led by the Italian archaeological mission have provided the opportunity to redate this important site with three main objectives: (1) to establish a precise and reliable chronology for the formation of the shell midden; (2) to calculate the marine reservoir age for the period of interest by ${ }^{14} \mathrm{C}$ dating coeval marine and terrestrial ecofacts in layers ranging from the bottom to the top of the stratigraphy; and (3) to redate the burials found at RH-6 using the mineral fraction of bones (bioapatite) as a dating material. Recent work has shown that bone apatite can substitute as a reliable dating material and an alternative to bone collagen in arid environments (Zazzo and Saliège 2011; Zazzo 2014). Several new graves were found during the 2012-2013 excavation campaigns (Marcucci et al. 2014), offering the opportunity to integrate the graveyard into a reliable chronology. These new dates will help us understand the dynamics of occupation and the abandonment of the site and will be integrated into the broader context of human occupation of the Qurum mangrove and its surroundings during the Neolithic.

\section{MATERIAL AND METHODS}

Thirty-eight samples of charcoal, shells, and human bones were selected for ${ }^{14} \mathrm{C}$ dating. Samples come from three different areas (sectors A, B and C) excavated by the Italian archaeological mission (Figure 2) (Marcucci et al. 2014). Sector A is a settlement area located at the eastern limit of the anthropic deposit, where the stratigraphic sequence does not exceed a height of $45 \mathrm{~cm}$. It provided one charcoal sample located in a posthole (SU 69) just above the bedrock. This posthole is related to the construction of HUT A2 (Marcucci et al. 2014). The three dated burials come from Sector B. This sector is located west of Sector A, at the top of the midden. The dated burials are located just under the surface of the midden and are primary deposits of adult individuals lying in a crouched position on their side. Three human bone samples (fragments of femur and tibia) together with two shells from Grave 2 were dated. One of the dated shells (Amiantis umbonella) was complete and placed on the right hand of the individual. This deposit evokes a well-known practice at RH-5, where several individuals were deposited with a Callista sp. valve in the hand or close to the face (Salvatori 2007). The other shell (Anadara sp.) was found in the outer limit of the pit showing a dip. Dating of this sample will provide insight into the amount of time elapsed between sediment accumulation and the digging of the grave. Most of the dating effort (32/38 dates) was concentrated on Sector $C$, which displays the deepest stratigraphic sequence $(1.70 \mathrm{~m})$. This sector is located in the western slope of the midden and corresponds broadly to the trench opened in 1975 (Tosi 1975) and later studied by Biagi during the 1980s (Biagi et al. 1984; Biagi 1985).

Most of the samples dated by Biagi come from two excavation areas (square X and Y) located at the southeastern end of the trench, where 14 stratigraphic layers were identified. During the 2012 excavation, the trench was refreshed and enlarged, and a new $2 \times 2 \mathrm{~m}$ excavation called Test Trench Z (TT-Z) was opened from the southwest section of the 1981 Trench. Among the 190 stratigraphic units (SU) identified, 
[Authors version] How to cite this article:

Antoine Zazzo, Olivia Munoz, Emilie Badel, Irène Béguier, Francesco Genchi and Lapo Gianni Marcucci (2016) A Revised Radiocarbon Chronology of the Aceramic Shell Midden of Ra's Al-Hamra 6 (Muscat, Sultanate of Oman): Implication For Occupational Sequence, Marine Reservoir Age, and Human Mobility. Radiocarbon, $58: 383$ - 395. Available on CJO 2016 doi:10.1017/RDC.2016.3

six (SU 2, SU 57, SU 117, SU 161, SU 164 and SU 185) were selected for ${ }^{14} \mathrm{C}$ dating. These units were selected because (1) they provided charcoal samples (with the exception of SU 2); (2) they were undisturbed; and (3) they spanned most of the sequence, allowing to estimate the change in MRA through time.

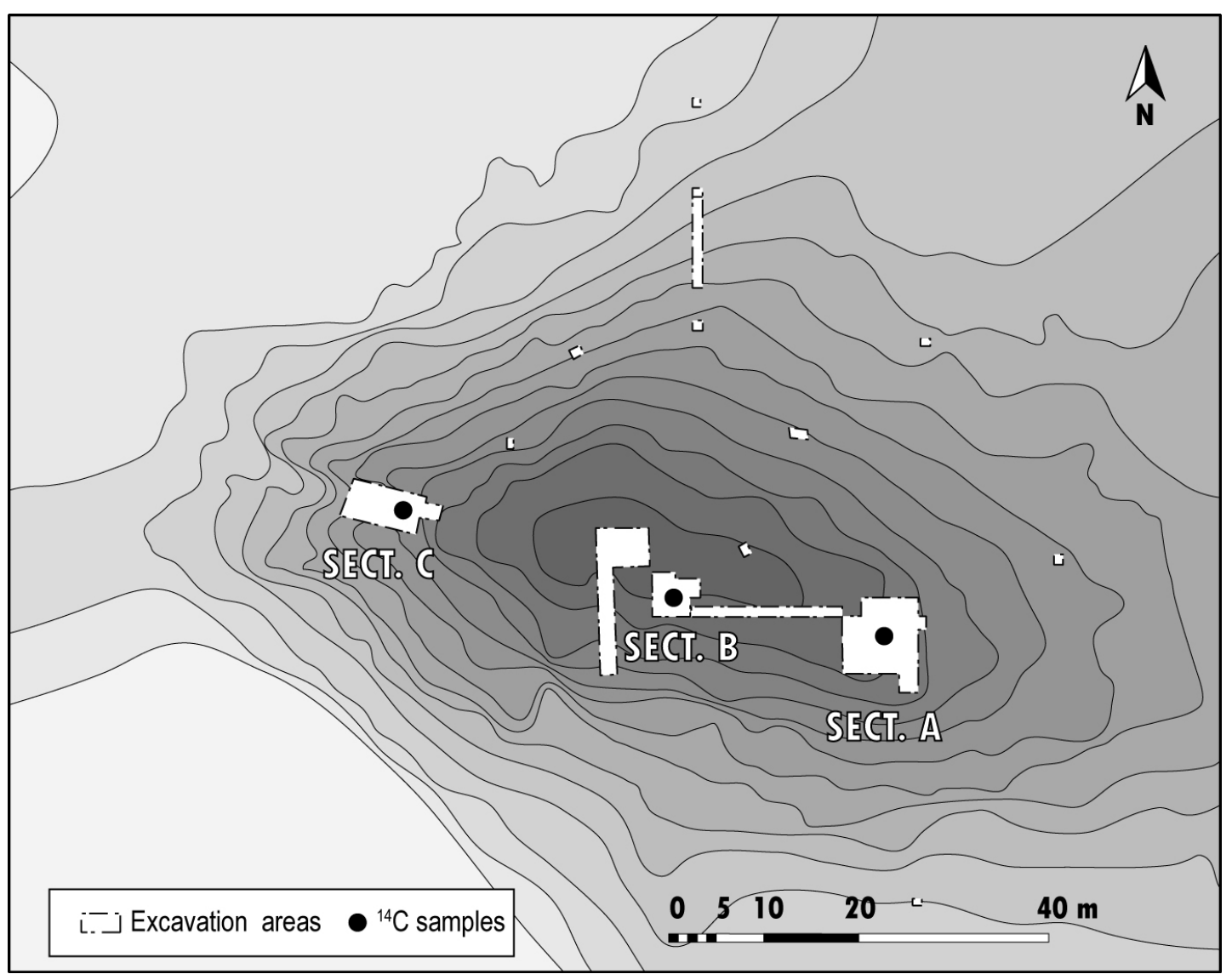

Figure 2 - Location of the three areas (Sector A, B, C) excavated by the Italian archaeological mission at RH-6.

Up to four charcoal and four shells were selected in each level. Charcoal and shells were identified to the genus or species level. Most of the charcoal belongs to the mangrove dwelling trees Rhizophora sp. and Avicennia marina. The bivalve mollusks are from Anadara antiquata and Amiantis umbonella. They were selected in priority because they are suspension feeders living in the sandy-muddy intertidal zone. The levels are briefly described here, from the uppermost to the lowermost layers. SU 2 was a sandy layer of greyish color that contained some broken shells (mainly Anadara sp.) and was cut by a large pit (PIT C2). Some beads made of Dentalium sp. and Pinctada sp. and a large worked gastropod (Lambis truncate sebae) have been found. SU 57 was a living floor cut by two postholes (TP C4 and C5) and one pit (PIT C4). It was a carbonaceous layer of darkish color that contained whole shells (Ostrea sp. and Anadara sp.) and other fragmentary ones (Terebralia palustris and Pinctada sp.). Many fish bones have been recovered, as well as a few mammalian and turtle remains. Objects discovered include a shell fish-hook, a bone point, a shell scraper (Veneridae), and few beads made of shell (Dentalium sp. and Engina mendicaria). SU 117 was a sandy layer of darkish color that contained broken shells (mainly Ostrea sp. and some Terebralia palustris, Anadara sp., Pinctada sp./Isognomon sp.) and many fish bones. Some objects and tools related to fishing activity have been found such as net sinkers, flat stones maybe used as cutting tools, and a bone fish-hook. It is worth mentioning that a few other daily life objects have also been recovered: a bone tool that may be a needle, a few fragments of large worked gastropods, a coloring stone (ochre), and beads made of shell (Dentalium sp. and Naticidae/Trochidae). SU 161 was a darkish sandy layer that contained many burnt fish bones and some fragmentary shells (Ostrea sp. and Terebralia palustris). This layer is closely linked to the upper one named SU 160, which was composed of ash. Both layers correspond to a combustion area that covered SU 164, which was a living floor made of small 
gastropods (Umbonium vestiarium) and round beach gravels. This layer was cut by TP C17, and covered by two combustion areas, SU160/ SU161 being one of them. Some beads made of shell (Dentalium sp. and Engina mendicaria) along with three bone tools (needles) and a flat stone (maybe a cutting tool) have been found.Finally, SU 185 was a sandy layer covering the bedrock, which contained very few shells (Ostrea sp. and Terebralia palustris). Charcoal found in SU 185 was grouped with charcoal found near trench TT-Z in postholes picked at the basis of trench 81 and 86.

Sample preparation was conducted at the radiocarbon laboratory of the Museum national d'histoire naturelle $(\mathrm{MNHN})$ in Paris. Because charcoals in arid environments are fragile, they were pretreated using a modified version of the acid-base-acid (ABA) method, using a diluted $(4 \times 10-3 \mathrm{~N}) \mathrm{NaOH}$ solution for $20 \mathrm{~min}$ at room temperature. The outer part of the shells (sample size $0.25-0.5 \mathrm{~g}$ ) was etched in $10 \% \mathrm{HCl}$ for $60 \mathrm{~s}$. This treatment caused a weight loss of $40 \pm 10 \%$. Human bones lacked collagen and the AMS date was performed on the inorganic (bioapatite) fraction of compact (femur or tibia) bone samples. Bone samples $(1-2 \mathrm{~g})$ were finely powdered $(<160 \mu \mathrm{m})$, then pretreated in $1 \mathrm{~N}$ acetic acid for $19 \mathrm{hr}$ under vacuum at room temperature. This treatment caused a weight loss of $47 \pm 6 \%$. Bleaching was not necessary because these bones lacked organic matter. Shell and bone samples were then hydrolyzed in $100 \%$ orthophosphoric acid for $10-20 \mathrm{~min}$ at $70^{\circ} \mathrm{C}$ and charcoal was combusted for $20 \mathrm{~min}$ at $800^{\circ} \mathrm{C}$ in the presence of oxygen. $\mathrm{CO}^{2}$ was cryogenically trapped in sealed tubes. Graphitization and AMS measurement were conducted at the LMC14 laboratory (Saclay, France) and ${ }^{14} \mathrm{C}$ dates were corrected for isotopic fractionation.

\section{RESULTS}

Results are presented in Table 1. Charcoal dates range from $6425 \pm 35$ to $5760 \pm 45 \mathrm{BP}$. The oldest charcoal date comes from Sector A and the youngest from the upper level SU 57 in Sector C. Shell dates range from $7145 \pm 30$ to $5660 \pm 40 \mathrm{BP}$. The oldest shell comes from the lowermost level in Sector C, while the youngest is the bivalve (Amiantis umbonella) in direct association with the buried individual from Grave 2 . This shell is much younger than the one originating from the sediment filling the pit (6355 $\pm 30 \mathrm{BP})$. Human bones returned the youngest ages, ranging from $5475 \pm 30$ to $5600 \pm 30 \mathrm{BP}$.

In order to evaluate the chronology of shell-midden formation, as well as changes in MRA through time, we used the OxCal v 4.2.3 calibration software and grouped the charcoal and shell dates from Sector C in four successive phases (Bronk Ramsey 2009). ${ }^{14} \mathrm{C}$ dates were calibrated using the IntCal13 and Marine13 calibration curves (Reimer et al. 2013). We followed the approach outlined in Bronk Ramsey and Lee (2013) in order to evaluate the offset between the calibrated dates and left the $\Delta \mathrm{R}$ value undetermined in the model with a possible range from -600 to $600{ }^{14} \mathrm{C}$ yr. The code of the model is shown in Table 2 . 
[Authors version] How to cite this article:

Antoine Zazzo, Olivia Munoz, Emilie Badel, Irène Béguier, Francesco Genchi and Lapo Gianni Marcucci (2016) A Revised Radiocarbon Chronology of the Aceramic Shell Midden of Ra's Al-Hamra 6 (Muscat, Sultanate of Oman): Implication For Occupational Sequence, Marine Reservoir Age, and Human Mobility. Radiocarbon, 58 : 383 - 395. Available on CJO 2016 doi:10.1017/RDC.2016.3

Table 1 - Radiocarbon measurements of the RH-6 samples

\begin{tabular}{|c|c|c|c|c|c|c|c|c|}
\hline Target \# & Sector & su & Species & Context / remarks & dated fraction & $Z(\mathrm{~cm})$ & ${ }^{14} \mathrm{C}$ age & error \\
\hline SacA 32918 & B & & Homo sapiens & Grave 1 & bone apatite & & 5475 & 30 \\
\hline SacA 32919 & B & & Homo sapiens & Grave 2 & bone apatite & & 5600 & 30 \\
\hline SacA 32920 & B & & Homo sapiens & Grave 3 & bone apatite & & 5520 & 30 \\
\hline SacA 32958 & A & 69 & Rhizophora sp. & Bedrock, TPT42 & charcoal & & 6425 & 35 \\
\hline SacA 32924 & C & 57 & Avicennia marina & near pit 4 & charcoal & $30-40$ & 5835 & 35 \\
\hline SacA 32930 & C & 117 & Avicennia marina & under SU108 & charcoal & $70-80$ & 5760 & 45 \\
\hline SacA 32926 & C & 117 & indet. & under SU108 & charcoal & $70-80$ & 5790 & 50 \\
\hline SacA 32927 & c & 117 & Rhizophora sp. & under SU108 & charcoal & $70-80$ & 5880 & 30 \\
\hline SacA 32925 & C & 117 & indet. & under SU108 & charcoal & $70-80$ & 5970 & 60 \\
\hline SacA 32933 & C & 161 & Rhizophora sp. & & charcoal & $120-130$ & 5915 & 35 \\
\hline SacA 33993 & C & 161 & Rhizophora sp. & & charcoal & $120-130$ & 5975 & 30 \\
\hline SacA 32939 & C & 164 & Avicennia marina & & charcoal & $120-130$ & 5980 & 35 \\
\hline SacA 32932 & C & 164 & Rhizophora sp. & & charcoal & $120-130$ & 6000 & 35 \\
\hline SacA 32940 & C & 164 & Rhizophora sp. & & charcoal & $120-130$ & 6005 & 35 \\
\hline SacA 32941 & C & 185 & Chenopodiaceae & & charcoal & $160-170$ & 6175 & 35 \\
\hline SacA 32956 & C & & Avicennia marina & $\begin{array}{c}\text { Bedrock, trench 89, } \\
\text { TP10 } \\
\text { Bedrock, trench 81, }\end{array}$ & charcoal & 170 & 6065 & 35 \\
\hline SacA 32957 & C & & Rhizophora sp. & $\begin{array}{c}\text { TP19 } \\
\text { Bedrock, trench 89, }\end{array}$ & charcoal & 170 & 6165 & 35 \\
\hline SacA 32955 & C & & Avicennia marina & TP8 & charcoal & 170 & 6220 & 30 \\
\hline SacA 32951 & B & & Amiantis umbonella & Grave 2, rr494 & shell & & 5660 & 30 \\
\hline SacA 32952 & B & & Anadara antiquata & Grave 2, edge pit & shell & & 6355 & 30 \\
\hline SacA 32922 & C & 2 & Anadara antiquata & & shell & $0-10$ & 6165 & 30 \\
\hline SacA 32921 & C & 2 & Anadara antiquata & & shell & $0-10$ & 6235 & 30 \\
\hline SacA 32923 & C & 2 & Anadara antiquata & & shell & $0-10$ & 6280 & 60 \\
\hline SacA 32928 & C & 57 & Anadara antiquata & & shell & $30-40$ & 6245 & 30 \\
\hline SacA 32934 & C & 57 & Anadara antiquata & & shell & $30-40$ & 6260 & 30 \\
\hline SacA 32929 & C & 57 & Anadara antiquata & & shell & $30-40$ & 6370 & 30 \\
\hline SacA 32936 & C & 117 & Anadara antiquata & & shell & $70-80$ & 6160 & 30 \\
\hline SacA 32937 & c & 117 & Anadara antiquata & & shell & $70-80$ & 6210 & 30 \\
\hline SacA 32935 & C & 117 & Anadara antiquata & & shell & $70-80$ & 6350 & 30 \\
\hline SacA 32938 & C & 117 & Anadara antiquata & & shell & $70-80$ & 6655 & 30 \\
\hline SacA 32942 & C & 161 & Anadara antiquata & & shell & $120-130$ & 6430 & 30 \\
\hline SacA 32943 & C & 164 & Anadara antiquata & & shell & $120-130$ & 6440 & 30 \\
\hline SacA 32944 & C & 164 & Anadara antiquata & & shell & $120-130$ & 6460 & 30 \\
\hline SacA 32945 & C & 164 & Anadara antiquata & & shell & $120-130$ & 6530 & 30 \\
\hline SacA 32946 & C & 185 & Anadara antiquata & & shell & $160-170$ & 6645 & 30 \\
\hline SacA 32948 & C & 185 & Anadara antiquata & & shell & $160-170$ & 6920 & 30 \\
\hline SacA 32949 & C & 185 & Anadara antiquata & & shell & $160-170$ & 6930 & 30 \\
\hline SacA 32950 & c & 185 & Anadara antiquata & & shell & $160-170$ & 7145 & 30 \\
\hline
\end{tabular}


[Authors version] How to cite this article:

Antoine Zazzo, Olivia Munoz, Emilie Badel, Irène Béguier, Francesco Genchi and Lapo Gianni Marcucci (2016) A Revised Radiocarbon Chronology of the Aceramic Shell Midden of Ra's Al-Hamra 6 (Muscat, Sultanate of Oman): Implication For Occupational Sequence, Marine Reservoir Age, and Human Mobility. Radiocarbon, 58 : 383 - 395. Available on CJO 2016 doi:10.1017/RDC.2016.3

Table 2-Oxcal code for RH-6 phase model with undetermined $\Delta R$ with a -600 to $60014 C$ yr range

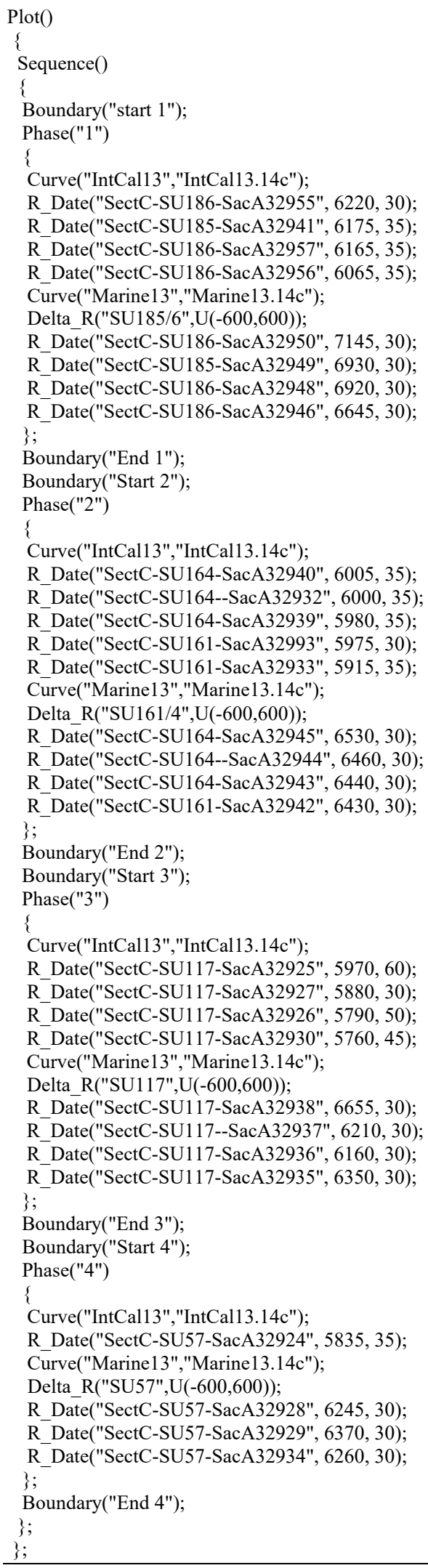


[Authors version] How to cite this article:

Antoine Zazzo, Olivia Munoz, Emilie Badel, Irène Béguier, Francesco Genchi and Lapo Gianni Marcucci (2016) A Revised Radiocarbon Chronology of the Aceramic Shell Midden of Ra's Al-Hamra 6 (Muscat, Sultanate of Oman): Implication For Occupational Sequence, Marine Reservoir Age, and Human Mobility. Radiocarbon, $58: 383$ - 395. Available on CJO 2016 doi:10.1017/RDC.2016.3

Table 3 summarizes the main outputs of the model, including the beginning and end of each phase and the modeled $\Delta \mathrm{R}$ and MRA values $\mathrm{R}$ in the $1 \sigma$ range. $\mathrm{R}$ values were calculated considering the global average offset of oceanic ${ }^{14} \mathrm{C}$ with respect to the atmosphere of $405 \pm 22{ }^{14} \mathrm{C}$ yr. The agreement value is high (Amodel $=96$ ), suggesting a robust model. The modeled distribution result indicates that RH-6 formation started during the mid- $6^{\text {th }}(5603-5391)$ and ended during the mid- $5^{\text {th }}(4587-4473)$ millennium cal BC. Positive $\Delta \mathrm{R}$ values are calculated throughout the entire sequence, ranging from $99 \pm 27$ (SU 161/4) to $207 \pm 43$ (SU 57) ${ }^{14} \mathrm{C} \mathrm{yr}$ (Figure 3). $\Delta \mathrm{R}$ value is poorly constrained at the bottom of the shell midden $\left(202 \pm 95{ }^{14} \mathrm{C} \mathrm{yr}\right)$, possibly due to some mixing. In contrast, $\Delta \mathrm{R}$ values calculated for the intermediate layers (SU 161/4 and SU 117) are well constrained.

Table 3 - Probability distribution (at one sigma) for the beginning and the end of the four phases, as well as the $\Delta R$ and $R$ values obtained from the modeled dates, using Oxcal v4.2.3 Bronk Ramsey (2009) and r.5 Marine data from Reimer et al. (2013).

\begin{tabular}{cccccccccccc}
\hline \multirow{2}{*}{ Phase } & $\begin{array}{c}\text { Stratigraphic } \\
\text { unit (SU) }\end{array}$ & \multicolumn{2}{c}{ start } & \multicolumn{2}{c}{ end } & \multicolumn{3}{c}{$\Delta \mathbf{R}$} & \multicolumn{4}{c}{$\mathbf{R}$} \\
& from & to & from & to & average & \pm & 1 SD & average & \pm & 1 SD \\
\hline \hline 1 & SU 185/6 & 5603 & 5391 & 4980 & 4900 & 202 & \pm & 96 & 607 & \pm & 97 \\
2 & SU 161/4 & 4933 & 4876 & 4897 & 4861 & 99 & \pm & 27 & 504 & \pm & 34 \\
3 & SU 117 & 4886 & 4843 & 4616 & 4558 & 144 & \pm & 25 & 549 & \pm & 33 \\
4 & SU 57 & 45599 & 4548 & 4587 & 4473 & 207 & \pm & 43 & 612 & \pm & 48 \\
\hline
\end{tabular}

An average $\Delta \mathrm{R}$ value of $163 \pm 51{ }^{14} \mathrm{C}$ yr was calculated based on the four estimates, corresponding to a local MRA correction $R$ value of $568 \pm 56{ }^{14} \mathrm{C}$ yr. In the absence of terrestrial material associated with the human burials, establishing the chronology of occupation of the graveyard is not straightforward. Furthermore, the likely contribution of marine resources in the diet of the RH-6 population does not allow us to use the human dates directly to estimate the period of occupation of the cemetery. However, it is possible to use the Amiantis umbonella date obtained in Grave 2 since this shell likely was deposited live in the hand of the buried individual. The date was calibrated using the average $\Delta \mathrm{R}$ value of $163 \pm 51{ }^{14} \mathrm{C}$ yr calculated above, providing an age range of 3996-3830 cal BC. A sensitivity test was also performed, using the minimum and maximum $\Delta \mathrm{R}$ values, but this had a minor impact $(<50 \mathrm{yr})$ on the age range. This suggests that there is a 500-700 yr hiatus between the formation of the midden and its later use as a graveyard. Using the Amiantis date and the average $\mathrm{R}$ value of $568 \pm 56{ }^{14} \mathrm{C}$ yr calculated above, we determined that the diet of the individual buried in Grave 2 was comprised $89 \%$ of marine food. The same approach could not be performed in Grave 1 and 3 because they did not provide contemporary charcoal or shell in association with the human remains. However, their proximity (both in terms of stratigraphy and of ${ }^{14} \mathrm{C}$ age) also suggests a marine-dominated diet for these individuals.

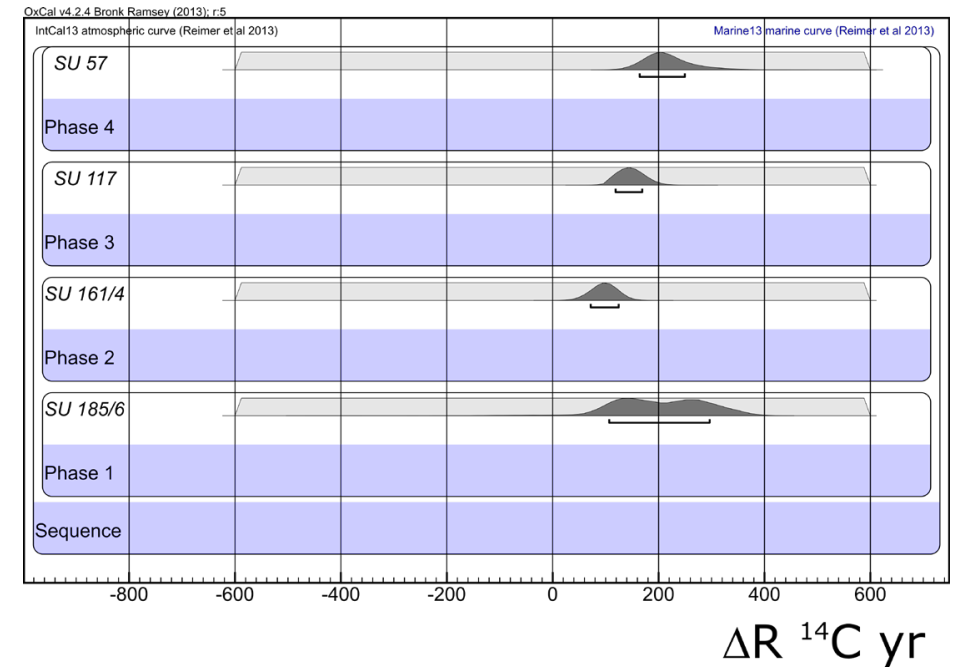

Figure 3 - Probability distribution (at $1 \sigma$ ) for the $\Delta R$ values of the four phases of the Bayesian model obtained from the modeled dates. 
[Authors version] How to cite this article:

Antoine Zazzo, Olivia Munoz, Emilie Badel, Irène Béguier, Francesco Genchi and Lapo Gianni Marcucci (2016) A Revised Radiocarbon Chronology of the Aceramic Shell Midden of Ra's Al-Hamra 6 (Muscat, Sultanate of Oman): Implication For Occupational Sequence, Marine Reservoir Age, and Human Mobility. Radiocarbon, 58 : 383 - 395. Available on CJO 2016 doi:10.1017/RDC.2016.3

\section{DISCUSSION}

\section{Chronology of Site Occupation}

The base level of RH- 6 dates to the mid- $6^{\text {th }}$ millennium cal BC and is contemporary with that of Suwayh 1, another shell-midden located further south along the Ja'alan coast (Charpentier et al. 2003). At that time, the sea level and the coastal landscape are similar to those today. The bulk of the shell-midden formation occurs between $4800-4400 \mathrm{cal} \mathrm{BC}$, at a time of sea-level rise corresponding to the maximum postglacial transgression observed elsewhere in the Makran and the Persian Gulf(Berger et al. 2013; Biagi 2013). This period corresponds to the second humid phase of the Holocene in the Arabian Peninsula, a time during which mangrove ecosystems were widely exploited by the Neolithic groups along the coasts of the Ja'alan and Indus delta. The most recent charcoal dates available for the shell midden (4700-4500 cal BC) seem to correspond to the peak of sea-level rise $(+2-3 \mathrm{~m})$. Bayesian modeling of the ${ }^{14} \mathrm{C}$ dates obtained at RH-6 suggests that there appears to be no human presence at the site during the second half of the $5^{\text {th }}$ millennium BC. It is impossible to discount the presence of people at other sites in the Ra's alHamra Peninsula, but RH-6 was abandoned for several centuries. Today, RH-6 is $7 \mathrm{~m}$ above sea level. A $2-3 \mathrm{~m}$ rise in sea level would induce major coastline shifts and would probably have surrounded the archaeological deposit. Although it is also not impossible that the upper part of the RH-6 sequence is missing due to erosion, this suggests that the abandonment of the site could have been triggered by the flooding of the plain around the midden. Interestingly, this period fits with the installation of human populations at the nearby coastal site of RH-5. The oldest charcoal date published for the site is $5480 \pm$ 60 BP (4457-4176 cal BC) (Biagi and Nisbet 1989). RH-5 is located on the tertiary limestone promontory of the Ra's al Hamra headland, $12 \mathrm{~m}$ above the water line, and would not have been affected by sea-level rise as much as RH-6. This succession in time seems to indicate permanent occupation of human groups in the area. The second period of occupation of RH-6, corresponding to its use as a cemetery, occurred at the beginning of the 4th millennium cal BC, at a time when sea level was slightly higher $(+1 \mathrm{~m})$ than today, but less than during the mid-5th millennium BC. This could be related to the second optimum of mangrove development attested between $3800-3500$ cal BC in the Ja'alan and the Indus Delta (Berger et al. 2013; Biagi 2013). No burials dating from the early $4^{\text {th }}$ millennium cal BC are known at RH-5 (Salvatori 2007) and individuals buried at RH-6 may be the ones that inhabited RH-5 in its earliest phase. As in RH-5, we lack the graves corresponding to the initial period of installation of the RH-6 population. This could be explained by practical issues (the bedrock is too hard to dig and the graves are not located on site), taphonomic issues (in absence of overlying sediment, mortuary disposals would have been more susceptible to be eroded), or funerary practices that do not leave traces. In this regard, Kutterer (2010) found charred human bones dating to the $6^{\text {th }}$ millennium cal BC in a cave at Fay-NE10 (central region of Sharjah, UAE), which suggest funerary treatment involving cremation. If such cremation practices were widespread throughout the Oman Peninsula before the $5^{\text {th }}$ millennium cal $\mathrm{BC}$, it could explain the absence/lack of human remains for this period, as charred bones could have been easily dispersed, and/or not recognized/identified as human remains during excavation among domestic refuses.

\section{Marine Reservoir Age}

The calibration of marine Omani shells has been an open question for many years. Previous estimates come from (1) ${ }^{14} \mathrm{C}$ dating of sediments from a marine core located on the continental margin off Pakistan (Staubwasser et al. 2002); and (2) terrestrial-marine pairs collected in shell middens from the $5^{\text {th }}$ to $4^{\text {th }}$ millennia cal BC along the coast of northern Oman (Uerpmann 1991; Biagi 1994; Zazzo et al. 2012, 2014). Published evidence derived from the marine core indicates that the MRA in the Arabian Sea is not only higher than the average ocean but also variable through time. For the period immediately preceding RH-6 (5695-6405 cal BC), the reservoir age is high $\left(1010{ }^{14} \mathrm{C}\right.$ yr; range: $\left.950-1250\right)$ and relatively well constrained (Staubwasser et al. 2002). No precise marine-based estimate exists for the period corresponding to RH-6 shell-midden formation, which seems to correspond to a period of change in the MRA. 
[Authors version] How to cite this article:

Antoine Zazzo, Olivia Munoz, Emilie Badel, Irène Béguier, Francesco Genchi and Lapo Gianni Marcucci (2016) A Revised Radiocarbon Chronology of the Aceramic Shell Midden of Ra's Al-Hamra 6 (Muscat, Sultanate of Oman): Implication For Occupational Sequence, Marine Reservoir Age, and Human Mobility. Radiocarbon, 58 : 383 - 395. Available on CJO 2016 doi:10.1017/RDC.2016.3

For the period following RH-6 shell-midden formation (4560-3550 cal BC), reservoir ages are not aswell constrained andmodeled reservoir ages cluster around two values $\left(640\right.$ and $980{ }^{14} \mathrm{C}$ yr $)$ of comparable likelihood. A reservoir age of $640 \pm 120{ }^{14} \mathrm{C} \mathrm{yr}$ (range: 520-740) was chosen, but the authors note that this value should be viewed with caution. No consensus value seems to emerge either from the ${ }^{14} \mathrm{C}$ dating of terrestrial-marine pairs collected in shell middens along the coast of northern Oman. ${ }^{14} \mathrm{C}$ dates measured by Biagi (1994) on associated charcoals and shells found at RH-6, once corrected from isotopic fractionation (assuming a $\delta^{13} \mathrm{C}$ value of zero for shell samples), suggest a MRA between 460 and $630{ }^{14} \mathrm{C}$ yr during the $5^{\text {th }}$ millennium. Similar low values were found for the $4^{\text {th }}$ millennium BC at RH-5 by the same author and were later confirmed by Zazzo et al. (2012, 2014). A much higher value of 800 yr was proposed by Uerpmann (1991), but this high MRA remains doubtful for two reasons: (1) it is based on only 2 out of the 6 pairs analyzed, while the remaining four span a wide range between 945 and $5240{ }^{14} \mathrm{C}$ yr; and (2) ash, not charcoal, was selected for most (5 out of 6 ) of the pairs and could have been subjected to contamination. Our results, obtained from a secure context (a stratified shell midden), suggest a much lower and consistent value comprised between about 500 and $600{ }^{14} \mathrm{C} \mathrm{yr}$ and confirm the previous estimates by Biagi (1994) and Zazzo et al. (2012, 2014). This result seems fairly well supported, especially in the intermediate layers (SU 161/4 and SU 117) where charcoal and shell ages are consistent. Finally, we note that our MRA estimate for the mid- $6^{\text {th }}$ millennium cal BC $\left(612 \pm 48{ }^{14} \mathrm{C}\right.$ yr $)$ is not significantly different than the modern pre-bomb value of $631 \pm 49{ }^{14} \mathrm{C}$ yr measured in the Muscat area (Southon et al. 2002). This observation suggests stability of the MRA in the Arabian Sea since the mid- $6^{\text {th }}$ millennium BC. Further work on more recent assemblages are required to confirm this conclusion.

\section{Human Diet and Mobility}

The ${ }^{14} \mathrm{C}$ dates obtained on contemporary human bone and shell in Grave 2 gave us a unique opportunity to precisely estimate the paleodiet of this individual. The two dates are only separated by $60{ }^{14} \mathrm{C} \mathrm{yr}$, suggesting a high proportion of marine and mangrove resources in the diet of this individual. Using the average MRA calculated for the period comprised between the $6^{\text {th }}$ and the $5^{\text {th }}$ millennium $\mathrm{BC}\left(568{ }^{14} \mathrm{C}\right.$ yr), we calculated that $89 \%$ of this individual's diet derived from marine resources. Although the MRA value might have changed during the course of the $5^{\text {th }}$ millennium $\mathrm{BC}$, sensitivity tests indicate that the reconstructed proportion of marine foods in this individual's diet is not strongly affected by this parameter. An uncertainty of $\pm 100{ }^{14} \mathrm{C}$ yr on the MRA value would only affect the marine proportion in the diet by $4 \%(87-91 \%)$ and would not fundamentally alter our conclusion. Such a high proportion of marine resources in the diet implies low mobility, or mobility restricted to the coast for the population of RH-6. This finding confirms previous archaeozoological and archaeobotanical observations showing the overwhelming presence of marine and mangrove dwelling species in the faunal and charcoal assemblage of the shell midden (Biagi and Travers 1985; Uerpmann and Uerpmann 2003; Wilkens 2005). This is also consistent with the results of the analysis of the raw materials used for lithic industry at Ra's al-Hamra (Maggi and Gebel 1990) indicating that most of the employed materials (quartz, chert, flint, olivine, steatite) were available less than $7 \mathrm{~km}$ away from the sites, as wadi gravels with nodules or outcrops. This mobility pattern can be easily explained by the large variety of resources offered by the local environment (Biagi and Nisbet 2006). A similar conclusion was reached for the population living a few centuries later in the nearby coastal site of RH-5 (Zazzo et al. 2014). Whatever the motivation of the habitat move from RH-6 to RH-5 may be, it seems that the group settled at RH-5 succeeded in adapting to the new constraints since the dense occupation of the site continued for more than 20 centuries. Despite possible changes in their social organization highlighted by differences in funerary practices, both groups share a marinedominated diet showing some continuity in the heavy dependence to the coastal resources between the $6^{\text {th }}$ and the $4^{\text {th }}$ millennium cal BC.

\section{ACKNOWLEDGMENTS}

We thank Camille Senelet for identification of the charcoal and shell samples, the CNRS INSHS for access to the Artemis facility, the team of the LMC14 for the graphitization and ${ }^{14} \mathrm{C}$ measurement of the $\mathrm{CO}^{2}$ samples, and Kita Macario for her help with the Bayesian modeling. We are grateful to the CNRS- 
[Authors version] How to cite this article:

Antoine Zazzo, Olivia Munoz, Emilie Badel, Irène Béguier, Francesco Genchi and Lapo Gianni Marcucci (2016) A Revised Radiocarbon Chronology of the Aceramic Shell Midden of Ra's Al-Hamra 6 (Muscat, Sultanate of Oman): Implication For Occupational Sequence, Marine Reservoir Age, and Human Mobility. Radiocarbon, 58 : 383 - 395. Available on CJO 2016 doi:10.1017/RDC.2016.3

INEE (PEPS "paléomangrove") and the Ministry of Heritage and Culture of the Sultanate of Oman for their financial support. This manuscript received constructive comments from Todd Braje, Paolo Biagi, and two other anonymous reviewers.

\section{REFERENCES}

Berger J-F, Charpentier V, Crassard R, Martin C, Davtian G, Lopez-Saez JA. 2013. The dynamics of mangroves ecosystems, changes in sea level and the strategies of Neolithic settlements along the coast of Oman (6000-3000 cal. BC). Journal of Archaeological Science 40(7):3087-104.

Biagi P. 1985. Excavation at the aceramic shell midden of RH-6, Qurm, Muscat. East and West 35(4):410-5.

Biagi P. 1994. A radiocarbon chronology for the aceramic shell-middens of coastal Oman. Arabian Archaeology and Epigraphy 5:17-31.

Biagi P. 1999. Excavations at the shell-midden of RH6 1986-1988 (Muscat, Sultanate of Oman). AlRafidan XX:57-84.

Biagi P. 2013. The shell middens of Las Bela coast and the Indus delta (Arabian Sea, Pakistan). Arabian Archaeology and Epigraphy 24(1):9-14.

Biagi P, Nisbet R. 1989. Some aspects of the 1982-1985 excavations at the aceramic coastal settlement of RH5 at Qurm (Muscat, Sultanate of Oman). In: Costa PM, Tosi M, editors. Oman Studies. Rome: IsMEO, Serie orientale Romana 9. p 31-46.

Biagi P, Nisbet R. 1992. Environmental history and plant exploitation at the aceramic sites of RH5 and RH6 near the mangrove swamp of Qurm (Muscat Oman). Bulletin de la Société Botanique de France. Actualités Botaniques 139(2-4):571-8.

Biagi P, Nisbet R. 1999. The shell-midden sites of RH5 and RH6 -Muscat, Sultanate of Oman). Archaeologia Polona 37:31-47.

Biagi P, Nisbet R. 2006. The prehistoric fishergatherers of the western coast of the Arabian Sea: a case of seasonal sedentarization? World Archaeology 38(2):220-58.

Biagi P, Travers RA. 1985. Non-mammalian osteological remains and fishing implements at RH-5 and RH6, Muscat. East and West 35(4):407-10.

Biagi P, Torke W, Tosi M, Uerpmann H-P. 1984. Qurum: a case study of coastal archaeology in northern Oman. World Archaeology 16(1):43-61.

Bronk Ramsey C. 2009. Bayesian analysis of radiocarbon dates. Radiocarbon 51(1):337-60. Bronk Ramsey C, Lee S. 2013. Recent and planned developments of the program OxCal. Radiocarbon 55(2-3):72030 .

Charpentier V, Marquis P, Pellé E. 2003. La nécropole et les derniers horizons Ve millénaire du site de Gorbat al-Mahar (Suwayh, SWY-1, Sultanat d'Oman): premiers résultats. Proceedings of the Seminar for Arabian Studies 33(33):11-9.

Hedges REM, Pettitt PB, Bronk Ramsey C, Van Klinken GJ. 1997. Radiocarbon dates from the Oxford
AMS System: Archaeometry datelist 23. Archaeometry 39(2):247-62.

Kutterer AU. 2010. Remarks on Neolithic burial customs in south-east Arabia. In: Weeks L, editor. Death and Burial in Arabia and Beyond, BAR International Series 2107. Oxford: Archaeopress.p $1-10$.

Maggi R, Gebel HG. 1990. A preliminary report on the chipped stones industries of the mid-holocene shell-midden communities of Ra's al-Hamra 5, Layer 1 (Sultanate of Oman). Rivista di Archeologia Anno XIV:5-24.

Marcucci LG, Badel E, Genchi F,Munoz O, Todero A, Tosi M. 2014. New investigations at the prehistoric shell midden of Ra's al-Hamra 6 (Sultanate of Oman): results of the 2012 and 2013 excavation seasons. Proceedings of the Seminar for Arabian Studies 44:235-56.

Munoz O. 2014. Pratiques funéraires et paramètres biologiques dans la péninsule d'Oman du Néolithique à la fin de l'âge du Bronze ancien (VIIIe mill. avant notre ère). Paris: Université de Paris 1 Panthéon-Sorbonne/Università di Roma La Sapienza. $540 \mathrm{p}$.

Reimer PJ, Bard E, Bayliss A, Beck JW, Blackwell PG, Bronk Ramsey C, Grootes PM, Guilderson TP, Haflidason H, Hajdas I, Hatté C, Heaton TJ, Hoffmann DL, Hogg AG, Hughen KA, Kaiser KF, Kromer B, Manning SW, Niu M, Reimer RW, Richards DA, Scott EM, Southon JR, Staff RA, Turney CSM, van der Plicht J. 2013. IntCal13 and Marine13 Radiocarbon age calibration curves 050,000 years cal BP. Radiocarbon 55(4):1869-87.

Salvatori S. 2007. The prehistoric graveyard of Ra's alHamra 5, Muscat, Sultanate of Oman. The Journal of Oman Studies 14:5-202.

Southon J, Kashgarian M, Fontugne M, Metivier B, Yim W. 2002. Marine reservoir corrections for the Indian Ocean and Southeast Asia. Radiocarbon 44(1):167-80.

StaubwasserM, Sirocko F, Grootes PM, Erlenkeuser H. 2002. South Asian monsoon climate change and radiocarbon in the Arabian Sea during early and middle Holocene. Paleoceanography 17:1063.

Tosi M. 1975. Notes on the distribution and exploitation of natural resources in ancient Oman. Journal of Oman Studies 1:187-206.

Uerpmann HP. 1991. Radiocarbon dating of shell middens in the Sultanate of Oman. PACT 29 : 335-47.

Uerpmann H-P, Uerpmann M. 2003. Stone Age sites and their natural environment. The Capital Area of Northern Oman, Part III. Beihefte zum Tübinger 
[Authors version] How to cite this article:

Antoine Zazzo, Olivia Munoz, Emilie Badel, Irène Béguier, Francesco Genchi and Lapo Gianni Marcucci (2016) A Revised Radiocarbon Chronology of the Aceramic Shell Midden of Ra's Al-Hamra 6 (Muscat, Sultanate of Oman): Implication For Occupational Sequence, Marine Reservoir Age, and Human Mobility. Radiocarbon, 58 : 383 - 395. Available on CJO 2016 doi:10.1017/RDC.2016.3

Atlas des Vorderen Orients Reihe A

(Naturwissenschaften), Nr. 31/3. Wiesbaden: Dr.

Ludwig Reichert Verlag.

Wilkens B. 2005. Fishing in the Arabian Sea: a short note on the prehistoric sites RH6 and Ra's al-Jinz 1 in Oman. Paléorient 31(1):126-30.

Zazzo A. 2014. Bone and enamel carbonate diagenesis: a radiocarbon prospective. Palaeogeography, Palaeoclimatology, Palaeoecology 416:168-78.

Zazzo A, Saliège J-F. 2011. Radiocarbon dating of biological apatites: a review. Palaeogeography, Palaeoclimatology, Palaeoecology 310(1-2):5261.

Zazzo A, Munoz O, Saliège J-F, Moreau C. 2012. Variability in the marine radiocarbon reservoir effect in Muscat (Sultanate of Oman) during the 4th millennium BC: reflection of taphonomy or environment? Journal of Archaeological Science 39(7):2559-67.

Zazzo A, Munoz O, Saliège J-F. 2014. Diet and mobility in a late Neolithic population of coastal Oman inferred from radiocarbon dating and stable isotope analysis. American Journal of Physical Anthropology 153(3):353-64. 